\title{
THE EFFECT OF ALARM SUBSTANCE ON PREDATION AMONG CYPRINIDS
}

\author{
BY F. J. VERHEIJEN \& J. H. REUTER* \\ Laboratory of Comparative Physiology, University of Utrecht, Jan van Galenstraat 40, The Netherlands
}

After the observation of an alarm reaction in the cyprinid Phoxinus laevis L. (von Frisch 1938) elaborate studies have revealed many details about the inter-relation between the liberation of alarm substance as a result of damage to the skin of a school member, and the alarm reaction of the school (see reviews by von Frisch 1941; Pfeiffer 1962, 1963a, 1966). Two functions have been suggested. First, to protect against predation in general by alarming the school members, and secondly, to protect fry against cannibalism and against predation by related species, primarily by alarming the predators. Some observations have supported the first view (von Frisch 1942) although many ethological and ecological aspects await further elucidation (Verheijen 1959; Gandolfi, Mainardi \& Rossi 1968). There is, however, hardly any evidence in favour of the second view.

Originally the suggestion that the alarm substance prevented cannibalism was based by von Frisch (1942) upon the observation of Berwein (1941) that minnows were frightened after eating young of their own species. This occurred mainly, however, when the prey had been damaged; when the prey had been swallowed at once cannibalism continued without the alarm reaction. Because of his finding that the alarm substance is produced by young minnows before they are themselves sensitive to it Schuitz (1956) supposed that the substance serves to frighten away preying adults. It can be argued, however, that the younger the fry the greater the chance that it will be swallowed at once and without being injured, consequently without perceptible quantities of alarm substance being liberated.

Previously Verheijen $(1962,1963)$ questioned whether this was the function of the alarm substance, because he had observed in an aquarium that creek chubs (Semotilus atromaculatus Mitchill) caught and swallowed smaller school members without being alarmed. This observation was criticized by Pfeiffer (1963a) because the fish had been freshly collected and were not

*Present address: Department of Physiology, Medical Faculty, Rotterdam, The Netherlands. familiarized with the experimental environment (von Frisch 1942), because the sensitivityPfeiffer erroneously used 'threshold'-of the fish would have been lowered, and because the very few aquarium observations could not be considered relevant to the natural situation. Moreover, Pfeiffer argued: 'Actually it was shown earlier that the alarm substance is really liberated when a minnow swallows a smaller minnow'. This is open to criticism in that this minnow was the northern squawfish (Ptychocheilus oregonense Richardson), a notorious predator which is anything but a typical representative of the cyprinids. According to Pfeiffer (1963b) it '.... fills the niche of the pike in British Columbia ...., and it is assumed that ‘. . large squawfish, when they become cannibalistic .... soon become indifferent to alarm substance in nature, as do the young squawfish in tanks', where "cannibalism is common'.

In order to get more experimental evidence we carried out three experiments, each consisting of a series of tests. In experiments 1 and 2 we observed in each test the behaviour of a school of respectively large roaches or large minnows after the introduction of some small roaches in the experimental tank. The suggestive agreement of the results of these admittedly rather improvised experiments with the previous observations of predation among cyprinids (Verheijen 1962, 1963) and among clupeids (Verheijen 1959) induced us to devise the more crucial experiment 3 in which the reactions of an isolated blinded minnow were studied after the introduction of water from a tank in which either a minnow or a small pike had preyed upon a small roach. The test minnow was blinded and observed in isolation because blinding and isolation increases the reactivity (Göz 1942).

\section{Methods}

The large roach (Leuciscus rutilus L.) used in experiment 1 ranged in size from 20 to $40 \mathrm{~cm}$ in length. They were allowed to become accustomed to the experimental tank with running tap 
water for 7 weeks after having been collected in the Biesbos (Rhine delta). All the minnows used in experiments 2 and 3 belonged to a shipment obtained from southern Germany through the kind cooperation of Professor von Frisch. These fishes were of a quite tame and reactive type in contradiction to schools obtained from other locations, for instance the Ardennes (Belgium), which proved to be persistently shy and difficult to work with. The minnows werc also allowed to become accustomed to the experimental tank before being tested. The small pike (Esox lucius L.) were 6 to $9 \mathrm{~cm}$ long and were obtained from the Netherlands Organization for Improvement of Inland Fisheries (O.V.B). The small roach introduced as a prey were collected in the vicinity of the laboratory. All fish were amply fed on Monday, Wednesday and Friday, the roach and minnows with chopped meat, the pike with worms or cyprinid fry. The experiments were carried out at arbitrary days so that the experimental fish might have been fed 1,2 or 3 days before a test. The test minnows used in experiment 3 were blinded by enucleation of the eyeball under MS 222 narcosis, and used a few days after they had resumed feeding.

The criteria used in deciding whether an alarm rcaction had occurred or not were of the usual subjective type. Care was taken not to overlook the slightest indicative changes in behaviour such as a closer crowding, a slight change in the rate of respiration or in the swimming speed, erection of fins etc. (weak reaction). An intense reaction of the blinded test minnow in experiment 3 was a sudden interruption of the continuous swimming, followed either by passively sinking or floating for several seconds, or by prolonged and panicstricken darting around. In experiment 3 an unsuccessful effort was made to use an objective and quantitative criterion for the degree of alarm by kymograph recording of the swimming level of the isolated and blinded test minnow, since we had the impression that in many cases an alarmed fish swam predominantly in the lower half of the aquarium whereas it seemed to move freely at any level when still undisturbed. In evaluating these recordings we did not succeed, however, in solving the statistical problems which arose from the fact that the moment at which the alarm substance reached the test fish could only be estimated very roughly. Consequently we had to be content with the more subjective criteria desçribed above,

\section{Experiment 1}

In the first experiment consisting of six tests a school of four large roach was in each test confronted in a tank $2 \times 2 \mathrm{~m}$ and $1 \mathrm{~m}$ high with five small roach of 4 to $5 \mathrm{~cm}$ in length.

\section{Results}

Invariably the small roach were chased and swallowed by the big ones. In all six tests the big fish showed no trace of an alarm reaction. Subsequent tests in which an extract of the skin of one small roach was introduced into the experimental tank revealed that the large roaches were insensitive to the alarm substance, because we observed only doubtful reactions in response to this fairly concentrated extract.

\section{Experiment 2}

In the second experiment consisting of three tests, five small roach about $2 \mathrm{~cm}$ long were introduced to five large minnows in a 250-1. tank. That roach measuring $2 \mathrm{~cm}$ have alarm substance and that minnows are fairly sensitive to it (von Frisch 1938; Schutz 1956) was confirmed by us in preliminary tests.

\section{Results}

In all three tests the large minnows did not stop chasing the small roach until the last one had been swallowed. No signs of an alarm reaction were observed in the minnows. Subsequent tests with a skin extract of one small 2$\mathrm{cm}-$ long roach confirmed the presence of the alarm substance and the sensitivity of the minnows to it as established in the preliminary tests.

\section{Experiment 3}

In the third experiment an isolated blinded minnow was observed in the middle of three 20-1. aquaria placed in a row; since dilution of alarm substance is less in smaller aquaria the chance of any reaction occurring is increased (von Frisch 1942). The middle one, provided with an outlet siphon, was connected by a siphon to each of the two other aquaria. Tap water was kept running into the middle one through the two outer aquaria. One of these two aquaria housed a small pike; the other housed two large minnows. Although the alertness is increased by pike odour (von Frisch 1942; Göz 1942), the continuous exposure to pike odour had no lasting observable effect on the blind minnow. In each test a small roach about $2 \mathrm{~cm}$ long was put either to the two minnows or to the pike, 


\section{Results}

After seventeen introductions of a small roach to two minnows, all resulting in predation, the blind minnow reacted slightly in only two cases which were among the five in which the small roach was not swallowed immediately by a minnow, so that the tail remained visible for some time. Out of the seven times a small roach was introduced to a pike and seized, an intense alarm reaction of the blind minnow was observed in six cases. By contrast with what we observed when preying occurred in the aquarium with two minnows, floating scales accompanied the swallowing of a roach by a pike. A pair of normal minnows and a blinded minnow, or a pike and a blinded minnow were used only once, so that all together we used seventeen pairs of normal minnows, seven pike and twentyfour blinded minnows. The distribution of whether or not alarm reactions occurred is presented in Table I.

Table I. The Distribution of Alarm Reactions of Blinded Test Minnows

\begin{tabular}{lcccc}
\hline & $\begin{array}{c}\text { Predation by } \\
\text { pike }\end{array}$ & $\begin{array}{c}\text { Predation by } \\
\text { minnow }\end{array}$ & Total \\
\hline Alarm reaction & 6 & 2 & 8 \\
No alarm reaction & 1 & 15 & 16 \\
Total & 7 & 17 & 24 \\
\hline
\end{tabular}

It is clear that alarm reactions occurred significantly more frequently after predation by pike than after predation by minnows $\left(\chi^{2}=12 \cdot 2\right.$, $P<0.005$ ).

\section{Discussion}

We should not deny alarm substance a function in reducing predation among cyprinids, but we think that the observations of Berwein (1941) and Verheijen $(1962,1963)$ and the experiments reported here will contribute to a correct evaluation of this function. The obvious tendency of freshly collected cyprinids to prey upon smaller fellow members of their species argues against reduction of this activity by the consequent production of alarm substance in nature. The observed intraspecific predation of clupeids in aquaria (Verheijen 1959) is compatible with data of the stomach content of several species of clupeids (for references see Verheijen 1959). As far as we know similar data are not available for cyprinids.

In our experiments the amount of alarm substance, if any, liberated when a large cyprinid swallowed a small one obviously was too small to alarm the predators. The sharply pointed teeth with which the mouth of a predator like the pike is abundantly provided are much more likely to damage the skin of a cyprinid prey, and thus to liberate the alarm substance, than the pharyngeal teeth of a preying cyprinid. Even if these pharyngeal teeth are of a sharp type as found in the carnivorous creek chub (Semotilus) (Lagler, Bardach \& Miller 1962), they do not necessarily damage a swallowed fellow member to such an extent that a sufficient amount of alarm substance will be liberated (Verheijen 1962, 1963). Moreover there are indications that, at least in some large species, the adult cyprinid may lose its sensitivity to the alarm substance.

The considerations about the function of alarm substance in reducing intra-specific predation are based upon the supposition that in the cyprinids intra-specific predation would be a detrimental factor. Cannibalism is, however, found among many suborders of fishes, and, at least in a number of non-cyprinid species, it seems to be of considerable significance for the survival of the species by regulating numbers during periods of food shortage (Nikolsky 1963).

\section{Summary}

1. Three experiments investigated whether predation among cyprinids is reduced by alarm substance.

2. In the first and second experiment large roach and large minnows respectively chased and swallowed small roach without an alarm reaction.

3 . In the third experiment blinded minnows showed an alarm reaction after the introduction into their tank of water out of a tank in which a pike had swallowed a small roach, whereas they did not react to water out of a tank in which a large minnow had swallowed a small roach.

4. The results do not support the view that one of the functions of alarm substance is to reduce intraspecific predation among cyprinids. It is doubtful whether such a predation is detrimental to the survival of the species.

\section{R E F E R E N C E S}

Berwein, M. (1941). Beobachtungen und Versuche über das gesellige Leben der Ellritze. $Z$. vergl. Physiol., 28, $402-420$.

Frisch, K. v. (1938). Zur Psychologie des FischSchwwarmes. Naturwịssenschaften, 26, 601-606, 
Frisch, K. v. (1941). Die Bedeutung des Geruchsinnes im Leben der Fische. Naturwissenschaften, 29, 321-333.

Frisch, K. v. (1942). Über einen Schreckstoff der Fischhaut und seine biologische Bedeutung. $Z$. vergl, Physiol., 29, 46-145.

Gandolfi, G., Mainardi, D. \& Rossi, A. C. (1968). The fright reaction of zebra fish. Atti Soc. ital. Sci. Nat. Museo Civico Storia Nat. Milano, 117, 74-88.

Göz, H. (1942). Über den Art- und Individualgeruch bei Fischen. Z. vergl. Physiol., 29, 1-45.

Lagler, K. F., Bardach, J. E. \& Miller, R. R. (1962). Ichthyology. New York: John Wiley and Sons.

Nikolsky, G. V. (1963). The Ecology of Fishes. London and New York: Academic Press.

Pfeiffer, W. (1962). The fright reaction of fish. Biol. Rev., $37,495-511$.

Pfeiffer, W. (1963a). Alarm substances. Experientia,
19, 113-123.

Pfeiffer, $W$. (1963b). The fright reaction in North American fish. Can. J. Zool., 41, 69-77.

Pfeiffer, W. (1966). Die Schreckreaktion der Fische und Kaulquappen. Naturwissenschaften, 22, 565-570.

Schütz, F. (1956). Vergleichende Untersuchungen über die Schreckreaktion bei Fischen und deren Verbreitung. $Z$. vergl. Physiol., 38, 84-135.

Verheijen, F. J. (1959). Absence of alarm substance in some clupeids. Pubbl. Staz. Zool. Napoli, 31, 146-152.

Verheijen, F. J. (1962). Alarm substance and intraspecific predation in cyprinids. Naturwissenschaften, 15, 356.

Verheijen, F. J. (1963). Alarm substance in some North American cyprinid fishes. Copeia, No. 1, 174-176.

(Received 14 August 1967; revised 4 July 1969; Ms. number: 768) 